\title{
The Impact of Hybrid Fibers on Punching Shear Strength of Concrete Flat Plates Exposed to Fire
}

\author{
Ahmed Naji Dalaf \\ Department of Civil Engineering \\ University of Baghdad \\ Baghdad, Iraq \\ ahmed_naji.2007@yahoo.com
}

\author{
Shatha Dheyaa Mohammed \\ Department of Civil Engineering \\ University of Baghdad \\ Baghdad, Iraq \\ shatha.dh@coeng.uobaghdad.edu.iq
}

\begin{abstract}
This study presents an investigation about the effect of fire flame on the punching shear strength of hybrid fiber reinforced concrete flat plates. The main considered parameters are the fiber type (steel or glass) and the burning steady-state temperatures $\left(500\right.$ and $\left.600^{\circ} \mathrm{C}\right)$. A total of 9 half-scale flat plate specimens of dimensions $1500 \mathrm{~mm} \times 1500 \mathrm{~mm} \times 100 \mathrm{~mm}$ and $1.5 \%$ fiber volume fraction were cast and divided into 3 groups. Each group consisted of 3 specimens that were identical to those in the other groups. The specimens of the second and the third groups were subjected to fire flame influence for 1 hour and steady-state temperature of 500 and $600^{\circ} \mathrm{C}$ respectively. Regarding the cooling process, water sprinkling was applied directly after the burning stage to represent the sudden cooling process. Generally, the obtained results exhibited a significant increase in the punching shear capacity of the fiber-reinforced slabs as compared to the corresponding no fiber-reinforced slabs even at elevated burning temperatures $600^{\circ} \mathrm{C}$. The ultimate load was increased by about $16.6,19$, and $21.5 \%$ at temperatures of 25 , 500 , and $600^{\circ} \mathrm{C}$ respectively, for steel fiber reinforced slabs and by about 13.9, 27.2 , and $34.6 \%$ for slabs containing two mixed types of fibers (steel and glass), as compared with the reference specimen at the same temperatures respectively. In addition, the results indicated that fibers' presence in concrete resulted in gradually punching failure with more ductile mode, whereas the failure was sudden with a brittle mode in the slabs that did not contain fibers.
\end{abstract}

\section{Keywords-steel fibers; hybrid fibers; punching shear}

\section{INTRODUCTION}

Flat plates are reinforced concrete slabs supported directly on columns without beams or girder system. Such slabs have a low capacity to transfer the shear loads to the columns due to their relatively small depth (thickness). As a result, most probable failure cases of flat plates are caused by higher shear stresses in the column connection. These failures are described as punching shear failures [1]. A punching shear failure takes place suddenly around the column in a particular collapse mechanism when a plug of concrete is pushed out from the slab immediately above the column [2]. Punching failure may occur due to slab overloading, un-conservative design for the slabcolumn connections, and deterioration in the strength of concrete and steel reinforcement resulted from the exposure of the slabs to fire [3]. At elevated temperatures, both steel and concrete exhibit a significant reduction in their strength, stiffness, and physical properties [4-7]. Some of these variables are not recoverable after sudden cooling, therefore, the punching strength of flat slabs subjected to fire is expected to be significantly affected [8]. Recently, a new technique using different types of fibers to improve the performance of concrete has been proven to give advanced outcomes [9-15]. The main objective of this study is to investigate experimentally the effect of fire on the punching shear strength of flat plates and the effect of adding fibers to the concrete mix as a solution to increase the resistance and ductility of slabs and to control cracking during fire exposure.

\section{LITERATURE REVIEW}

An experimental study about the effect of fire on some mechanical properties of concrete was carried out in [16]. The compressive strength of concrete was measured for $150 \mathrm{~mm}$ cubes whereas the flexural strength was measured for $100 \times 100 \times 400 \mathrm{~mm}$ prisms. The specimens were subjected to fire with temperatures between 25 and $700^{\circ} \mathrm{C}$. Three temperature levels of 400,500 , and $700^{\circ} \mathrm{C}$ were chosen with 4 different exposure durations $(0.5,1.0,1.5$, and $2.0 \mathrm{~h})$. The specimens were heated and cooled under the same regime and tested after exposure to fire. The results showed that the residual compressive strength ranged between $70 \%$ and $85 \%$ at $400{ }^{\circ} \mathrm{C}, 59 \%$ and $78 \%$ at $500{ }^{\circ} \mathrm{C}$, and $43 \%$ and $62 \%$ at $700{ }^{\circ} \mathrm{C}$. The flexural strength was found to be more sensitive to flame exposure than the compressive strength. The residual flexural strength ranged between $67 \%$ and $78 \%$ at $400{ }^{\circ} \mathrm{C}, 40 \%$ and $67 \%$ at $500^{\circ} \mathrm{C}$, and $20 \%$ and $45 \%$ at $700^{\circ} \mathrm{C}$. Authors in [17] studied the behavior and capacity of Steel Fiber Reinforced Concrete (SFRC) flat slabs under punching shear force. The results showed that steel fiber improved the punching shear resistance of the slabs considerably. Using steel fiber (30 to $60 \mathrm{~kg} / \mathrm{m}^{3}$ ) increased punching shear resistance of the slabs from $9.0 \%$ to $39.8 \%$ and this increase was directly proportional to fiber volume fraction. Steel fiber reduced significantly the average crack width of the slabs up to approximately $70.8 \%$.

\section{EXPERIMENTAL WORK}

The experimental work comprised 9 half-scale two-way specimens of $1500 \times 1500 \times 100 \mathrm{~mm}$ that were designed according to the ACI-318M-2019 [18] requirements as a

Corresponding author: Ahmed Naji Dalaf 
simply supported specimen over an effective span of $1400 \mathrm{~mm}$. The specimens were fiber reinforced by $1.5 \%$ volume fraction to investigate the effect of fire on the punching shear strength of fiber reinforced concrete flat plates. The geometrical layout and the reinforcement details are shown in Figure 1.

(a)

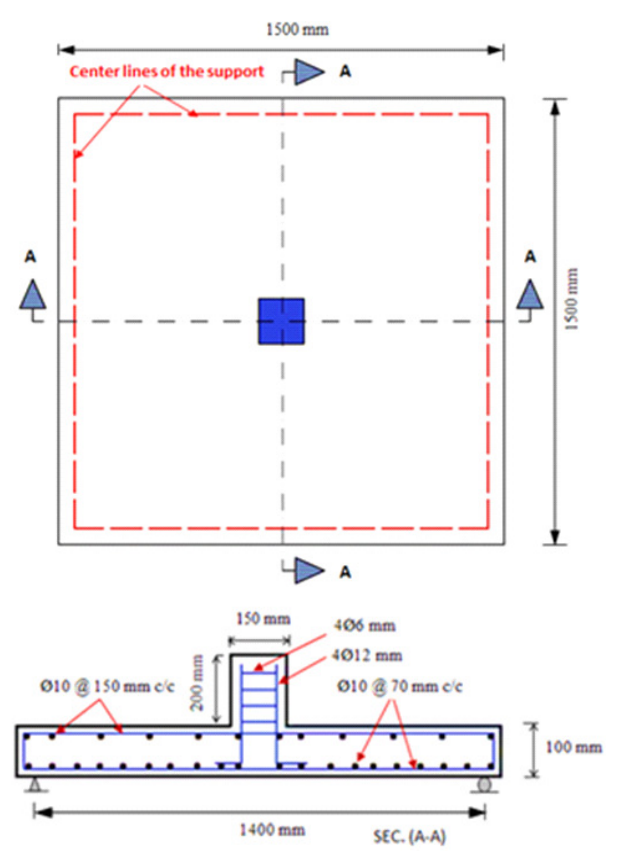

Fig. 1. Details of the tested specimens.

The 9 specimens were divided according to the steady state temperature into 3 groups, where each group consisted of 3 specimens, as can be seen in Table I, where NFC means No Fiber Content, SF1.5 means Steel Fiber with volume fraction of $1.5 \%$, GF0.5-SF1 means a mix of Glass $0.5 \%$ and Steel Fiber $1 \%$ and F500 or F600 represented the fire exposure at temperatures of 500 or $600^{\circ} \mathrm{C}$ respectively.

TABLE I. DETAILS OF THE SPECIMENS GROUPS

\begin{tabular}{|c|c|c|}
\hline Group No. & Slab designation & Steady state fire temperature $\left({ }^{\mathbf{0}} \mathbf{C}\right)$ \\
\hline \multirow{3}{*}{ Group 1 } & NFC-NF & No fire effect \\
\cline { 2 - 3 } & SF1.5-NF & No fire effect \\
\cline { 2 - 3 } & GF0.5-SF 1-NF & No fire effect \\
\hline \multirow{3}{*}{ Group 2 } & NFC-F500 & 500 \\
\cline { 2 - 3 } & SF 1.5-F500 & 500 \\
\cline { 2 - 3 } & GF0.5-SF1-F500 & 500 \\
\hline \multirow{3}{*}{ Group 3 } & NFC-F600 & 600 \\
\cline { 2 - 3 } & SF1.5-F600 & 600 \\
\cline { 2 - 3 } & GF0.5-SF1-F600 & 600 \\
\hline
\end{tabular}

The specimens in Groups 2 and 3 were tested in punching conditions after being exposed to fire for $1 \mathrm{~h}$ in order to study the effect of steady state temperature simultaneously with a uniform equivalent dead load $\left(8 \mathrm{kN} / \mathrm{m}^{2}\right)$ that represented $40 \%$ of the service design load (Figure 2). After the burning process, sudden cooling by water sprinkling took place to reduce the temperature.

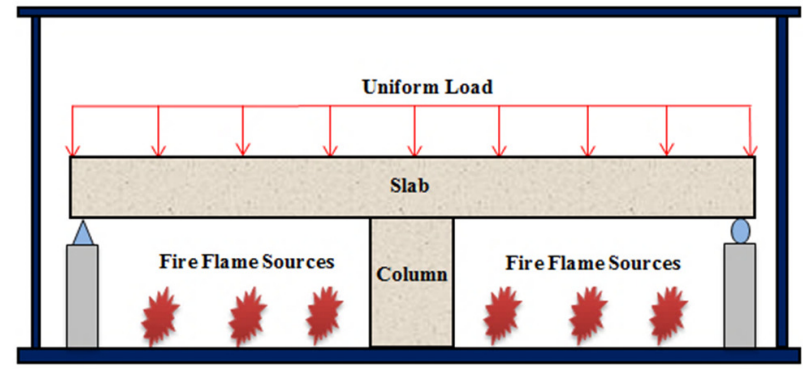

Fig. 2. Burning setup.

\section{MATERIALS AND METHODS}

The concrete mix was made from cement (Type I), coarse aggregates of $12 \mathrm{~mm}$ maximum size and Zone 2 fine aggregates. Steel and glass fibers were added to the concrete mix. The specimens were covered with polythene sheets for $24 \mathrm{~h}$ to avoid cracks caused by moisture loss, then they were cured by covering with damp canvases soaked with water continuously for 28 days to ensure good curing treatment. The characteristics of the considered fibers are reported in Table II. All the specimens were reinforced using deformed steel bars of $10 \mathrm{~mm}$ diameter at $70 \mathrm{~mm} \mathrm{c} / \mathrm{c}$ for each direction regarding the tension zone and at $150 \mathrm{~mm} \mathrm{c/c}$ for each direction in the compression zone. The steel yield strength was 470MPa. For each specimen, the compressive strength of concrete was measured for 3 standard $150 \times 300 \mathrm{~mm}$ cylinders subjected to the same burning conditions of the corresponding specimen. Table III shows the adopted concrete mixes proportions.

TABLE II. PROPERTIES OF THE STEEL AND GLASS FIBERS.

\begin{tabular}{|c|c|c|c|c|}
\hline Fiber type & $\begin{array}{c}\text { Length } \\
(\mathbf{m m})\end{array}$ & $\begin{array}{c}\text { Diam eter } \\
(\mathbf{m m})\end{array}$ & $\begin{array}{c}\text { Tensile } \\
\text { strength } \mathbf{( M P a})\end{array}$ & $\begin{array}{c}\text { Aspect ratio } \\
\left(\mathbf{L}_{\mathbf{f}} / \mathbf{D}_{\mathbf{f}}\right)\end{array}$ \\
\hline Steel fiber & 30 & 0.375 & 1700 & 80 \\
\hline Glass fiber & 30 & 0.6 & 1200 & 50 \\
\hline
\end{tabular}

TABLE III. CONCRETE MIXES' PROPORTIONS.

\begin{tabular}{|c|c|c|c|}
\hline Mix Type & NFC & MSF (1.5) & MGS (0.5\&1) \\
\hline Cement (kg/m3) & 420 & 420 & 420 \\
\hline Sand (kg/m3) & 490 & 490 & 490 \\
\hline Gravel (kg/m3) & 1042 & 1042 & 1042 \\
\hline w/c & 0.45 & 0.45 & 0.45 \\
\hline Super plasticizer (L/m3) & 3 & 3 & 3 \\
\hline Steel fiber (\%) & --- & 1.5 & 1 \\
\hline Glass fiber (\%) & --- & --- & 0.5 \\
\hline
\end{tabular}

\section{TESTED SPECIMENS AND INSTRUMENTATIONS}

The specimens of Groups 2 and 3 were burned before the punching test, in a furnace with inner dimensions of $3500 \times 2000 \times 900 \mathrm{~mm}$ used for the purpose. The fire source consisted of 20 methane burner nozzles distributed at the bottom of the furnace sides and the temperature was monitored by a digital thermometer reader of ATP DT-612 model, and a thermocouple sensor wire type $\mathrm{K}$ as shown in Figure 3. All the specimens were tested in punching test conditions as simply supported and loaded using one concentrated load applied at the center of the column. The vertical deflection at each 
loading stage was measured using mechanical dial gauges of $0.01 \mathrm{~mm}$ sensitivity allocated at the center and at the quarter span in each direction. Figure 4 shows the punching test setup.
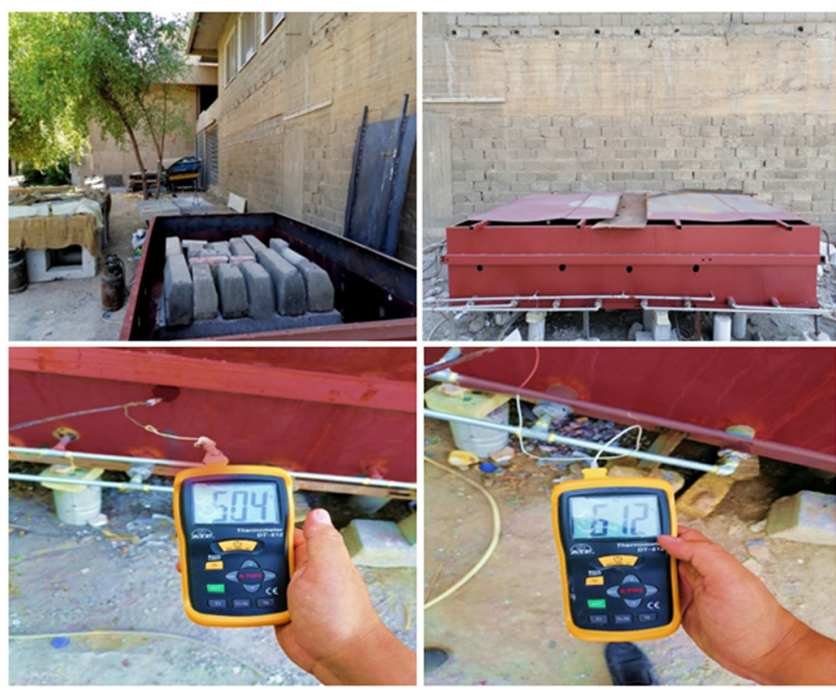

Fig. 3. Furnace and burning procedure.

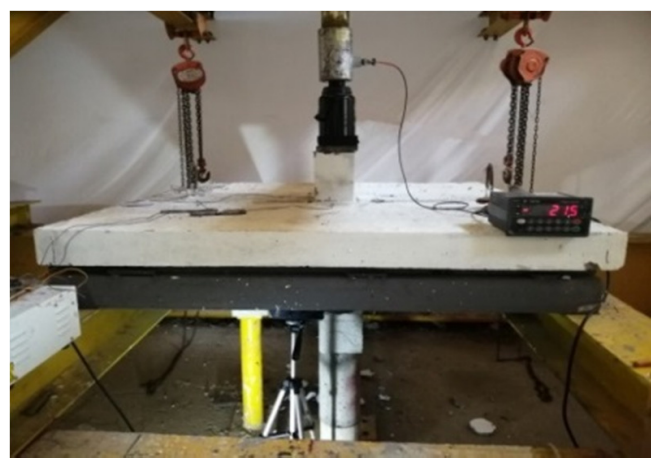

Fig. 4. Test setup.

\section{ResUlTS AND DISCUSSION}

\section{A. Initial Crack Load (Pcr) and Ultimate Punching Load (Pu)}

Table IV shows the initial crack (Pcr) and the ultimate punching $(\mathrm{Pu})$ loads. The results proved that adding fibers to the concrete mix increases the initial crack load and the ultimate load for all the tested specimens even at high elevated temperatures $\left(600^{\circ} \mathrm{C}\right)$ since the fibers bridge the tensile cracks and allows the transferring of the stresses through the opposite sides of the cracks. This means that slab tension zone is still able to resist additional stresses. From the results of Group 1 (Table IV) it can be concluded that specimen SF1.5-NF of $1.5 \%$ steel fiber volume fraction presented the optimum improvement in the initial crack load and the ultimate load by about $40 \%$ and $16.6 \%$ respectively, as compared with the reference specimen NFC-NF. The highest improvement in the initial crack load and the ultimate load for the burned specimens was recorded in the models GF0.5-SF1-F500 and GF0.5- SF1-F600 which contained two types of fibers (steel and glass fiber). The modification percentages reached $63.1 \%$ and $27.2 \%$ and $96.3 \%$ and $34.6 \%$ for steady state temperatures of 500 and $600^{\circ} \mathrm{C}$ respectively, as compared with the reference specimen of each group. The disadvantage behavior for the burned specimens SF1.5-F500 and SF1.5-F600 belongs to the considerable thermal expansion level of steel material $\left(10 \times 10^{-6} /{ }^{\circ} \mathrm{C}\right)$ compared with those of concrete and glass materials $\left(10 \times 10^{-6} /{ }^{\circ} \mathrm{C}\right.$ and $4.9 \times 10^{-6} /{ }^{\circ} \mathrm{C}$ respectively). The ratio $(1.5 \%)$ of steel fibers resulted in a substantial reduction in the concrete compressive strength in comparison with the ratio (1\%) due to the expansion damage effect of the steel fiber which was greater in the $1.5 \%$ specimen at the adopted burning temperatures $\left(500\right.$ and $\left.600^{\circ} \mathrm{C}\right)$. Moreover, hybrid fibers of different sizes and styles provide different restriction conditions, and these conditions can be the result of the mechanical bond strength modification since each type can delay micro-crack formation and prevent their propagation [19].

TABLE IV. INITIAL CRACK AND ULTIMATE LOAD RESULTS

\begin{tabular}{|c|c|c|c|c|c|c|}
\hline Group & Specimens & $\begin{array}{c}f^{\prime}{ }_{c} \\
(\mathbf{M P a})\end{array}$ & $\begin{array}{c}\mathbf{P}_{\mathrm{cr}} \\
(\mathrm{kN})\end{array}$ & $\begin{array}{c}\text { Increase in } \\
P_{\text {cr }} \%\end{array}$ & $\begin{array}{c}\mathbf{P}_{\mathrm{u}} \\
(\mathrm{kN})\end{array}$ & $\begin{array}{c}\text { Increase in } \\
P_{u} \% \\
\end{array}$ \\
\hline \multirow{3}{*}{1} & NFC-NF & 35.52 & 50 & --- & 180 & --- \\
\hline & SF1.5-NF & 40.32 & 70 & 40 & 210 & 16.6 \\
\hline & $\begin{array}{c}\text { GF0.5-SF 1- } \\
\text { NF } \\
\end{array}$ & 39.2 & 68 & 36 & 205 & 13.9 \\
\hline \multirow{3}{*}{2} & NFC-F500 & 21.81 & 38 & --- & 147 & --- \\
\hline & SF1.5-F500 & 26.37 & 53 & 39.5 & 175 & 19 \\
\hline & $\begin{array}{c}\text { GF0.5-SF 1- } \\
\text { F500 } \\
\end{array}$ & 28.24 & 62 & 63.1 & 187 & 27.2 \\
\hline \multirow{3}{*}{3} & NFC-F600 & 18.36 & 27 & --- & 130 & --- \\
\hline & SF1.5-F600 & 21.83 & 40 & 48.1 & 158 & 21.5 \\
\hline & $\begin{array}{c}\text { GF0.5-SF 1- } \\
\text { F600 }\end{array}$ & 25.85 & 53 & 96.3 & 175 & 34.6 \\
\hline
\end{tabular}

\section{B. Load-Deflection Relationships}

Figure 5 shows the load-deflection relationships for the unburned and burned specimens at 500 and $600^{\circ} \mathrm{C}$ respectively. Two zones were recognized in the unburned specimens' curves. The first refers to the behavior up to the initial crack load generation where the responses of all the tested specimens were similar and approximately linear. The second zone extended beyond the initial crack load generation during which other cracks were developed and the slope of the loaddeflection curves was decreased rapidly as a result of specimen stiffness reduction. Different behavior in the burned specimens at $500^{\circ} \mathrm{C}$ was detected, i.e. the linear stage limit was reduced. Moreover, in the case of $600^{\circ} \mathrm{C}$, the behavior was completely nonlinear due to the increasing fire-induced damage. In Figure 5(b)-(c), a strain hardening case can be observed in the reference specimens resulting from the highly fire damaged concrete which led to an increase of the steel reinforcement stresses. This case was prevented in the fiber reinforced specimens, since the steel fiber bridges the concrete parts and softens their tensile strength behavior. Moreover, it can be observed that, at the same level of loading, fiber reinforced specimens (unburned and burned) had less deflection than that of the reference specimens (without fiber) since fiber enhances the stiffness of the specimens due to its bridging role between the two sides of cracks and this can be noticed more vividly beyond the cracking stage. For the same level of loading, the 
specimen of $1.5 \%$ steel fiber had the minimum deflection of Group 1 (Figure 5 (a)), whereas the specimens that contained two types of fibers showed less deflection (Figure 5(b)-(c)). This usually reflects specimen stiffness modification.

(a)
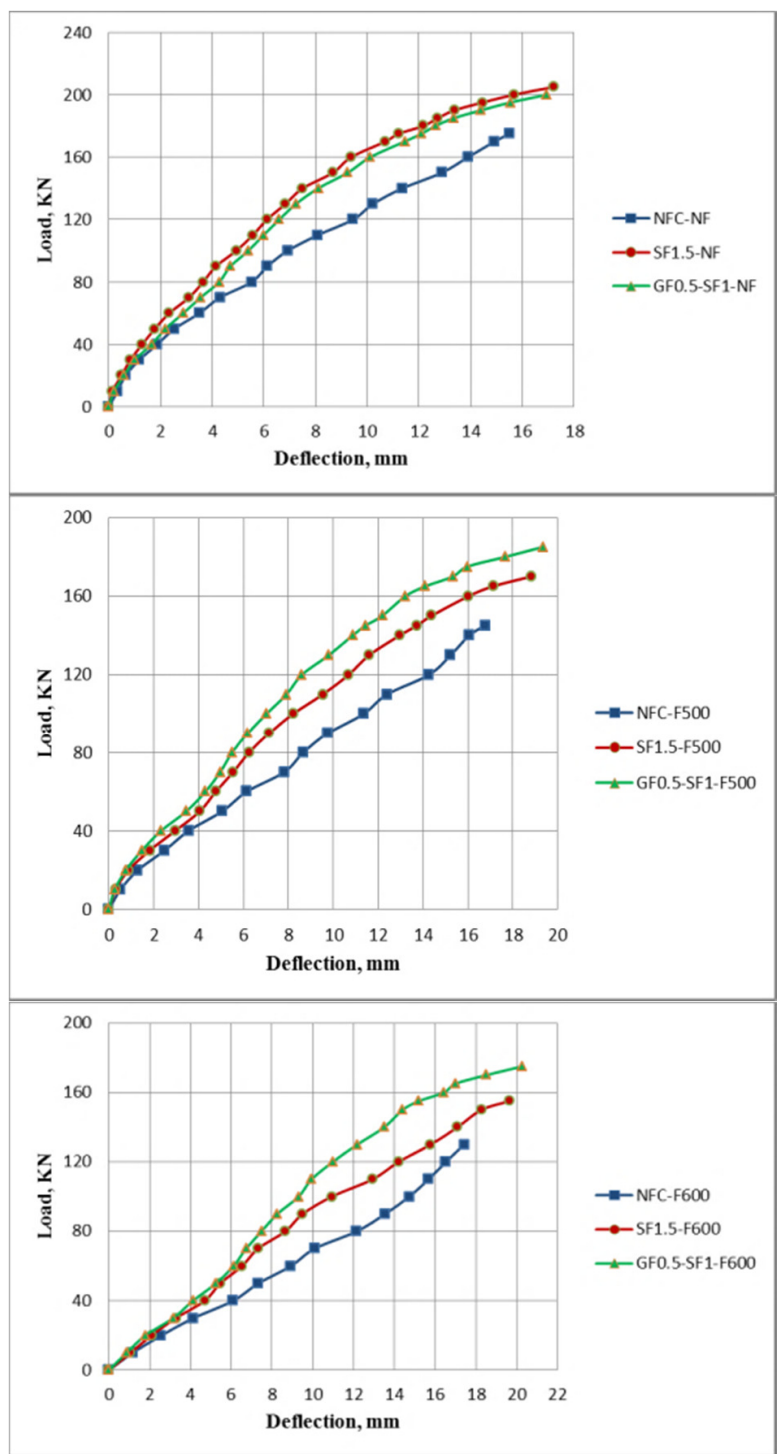

Fig. 5. Load- deflection curves: (a) Group 1, (b) Group 2, (c) Group 3.

Table V symmetrizes the outcomes of the tested specimens including the ultimate punching loads and their corresponding ultimate deflections. The specimens were grouped according to the fiber's type (no fiber, steel fiber, and mixed fibers). In general, there is a significant reduction in the punching shear resistance with an increase in the peak deflection of the burned specimens compared with the corresponding unburned specimens. The maximum drop $(27.78 \%)$ in the punching load was detected at $600^{\circ} \mathrm{C}$ burning temperature by the specimen NFC-F600. This was improved to $24.76 \%$ when steel fiber was added whereas the optimum modification was presented by the specimen GF0.5-SF1-F600 in which the reduction percentage was $14.63 \%$. The main reason for this is that the fire damage caused a reduction in the stiffness of the burned slabs.
TABLE V. VARIATION IN THE ULTIMATE LOAD AND DEFLECTION AT DIFFERENT BURNING TEMPERATURES

\begin{tabular}{|c|c|c|c|c|c|}
\hline Specimen & $\begin{array}{c}\text { Temperature } \\
\left.\mathbf{(}^{\mathbf{0}} \mathbf{C}\right)\end{array}$ & $\begin{array}{c}\mathbf{P u} \\
\mathbf{( k N )}\end{array}$ & $\begin{array}{c}\text { Reduction } \\
\mathbf{i n ~} \mathbf{P u} \%\end{array}$ & $\begin{array}{c}\text { Ultimate } \\
\text { deflection } \mathbf{\Delta u} \\
(\mathbf{m m})\end{array}$ & $\begin{array}{c}\text { Increase } \\
\text { in } \Delta \mathbf{u} \%\end{array}$ \\
\hline NFC-NF & 25 & 180 & ---- & 15.50 & ---- \\
\hline NFC-F500 & 500 & 147 & 18.33 & 16.76 & 8.13 \\
\hline NFC-F600 & 600 & 130 & 27.78 & 17.42 & 12.39 \\
\hline SF1.5-NF & 25 & 210 & ---- & 17.22 & ---- \\
\hline SF1.5-F500 & 500 & 175 & 16.67 & 18.86 & 9.52 \\
\hline SF1.5-F600 & 600 & 158 & 24.76 & 19.65 & 14.11 \\
\hline $\begin{array}{c}\text { GF0.5-SF1- } \\
\text { NF }\end{array}$ & 25 & 205 & ---- & 16.95 & --- \\
\hline $\begin{array}{c}\text { GF0.5-SF1- } \\
\text { F500 }\end{array}$ & 500 & 187 & 8.78 & 19.33 & 14.04 \\
\hline $\begin{array}{c}\text { GF0.5-SF1- } \\
\text { F600 }\end{array}$ & 600 & 175 & 14.63 & 20.28 & 19.65 \\
\hline
\end{tabular}

\section{Crack Patterns}

After the burning stage, there were hair cracks distributed randomly on the burned surface of the specimens as shown in Figure 6. These hair cracks were more in number and more clearly observed in the burned specimens at $600^{\circ} \mathrm{C}$. For all the tested specimens, additional cracks appeared around the column at the tension face of the tested specimen, during the loading stage. When the applied load was further increased, these cracks' were width and number increased and they were extended diagonally towards the specimens' edges causing failure in punching mode as shown in Figure 7.

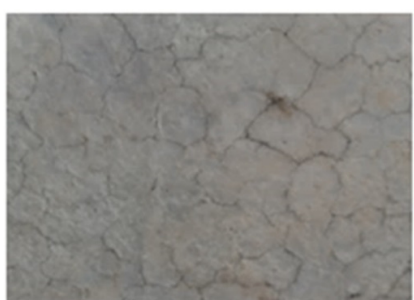

(a)

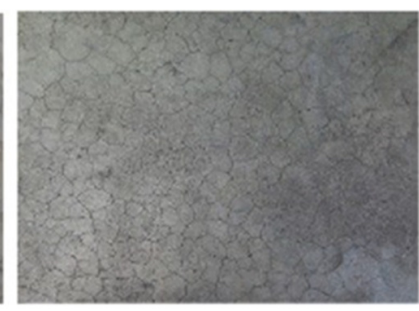

(b)
Fig. 6. Hair cracks in the burned specimens at (a) $500^{\circ} \mathrm{C}$, (b) $600^{\circ} \mathrm{C}$.

Actually, fibers decreased the crack width for both unburned and burned specimens. The average maximum crack width in Group 1 was $0.65 \mathrm{~mm}$ for no fiber specimens and $0.50 \mathrm{~mm}$ for fiber reinforced specimens. In Group 2, it was $0.80 \mathrm{~mm}$ for specimens without fibers and $0.60 \mathrm{~mm}$ for fiber reinforced specimens, whereas in Group 3, it was 0.95 and $0.70 \mathrm{~mm}$ respectively. It was also noticed that the punching failure in the reference specimens (without fiber) was sudden with brittle mode, whereas the fiber reinforced specimens failed in a gradual way with a more ductile mode since the fiber presence in the concrete mix improved the specimens' ductility by increasing the ultimate deflection. The burned reference specimens NFC-F500 and NFC-F600 exhibited extensive cover spalling in the tension side of the specimens at failure stage resulting from the strength deterioration of concrete caused by burning. In the fiber reinforced specimens, the spalling in the concrete cover was more controlled. This indicates that fiber presence in the concrete mix contributes to the connection between the damaged concrete parts in the tension side of the specimens. 

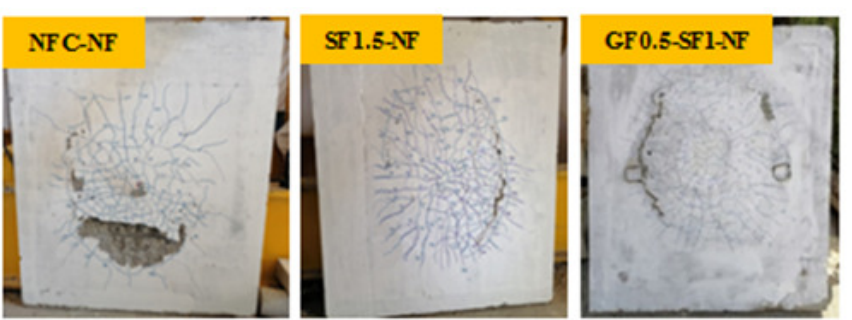

(a)
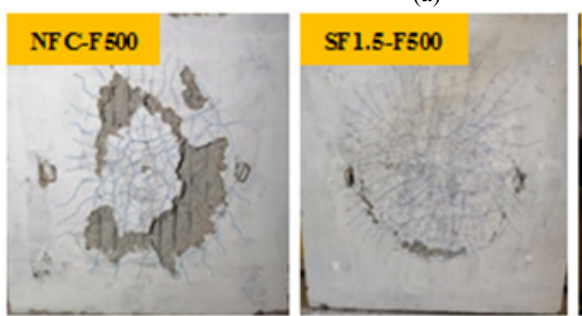

(b)
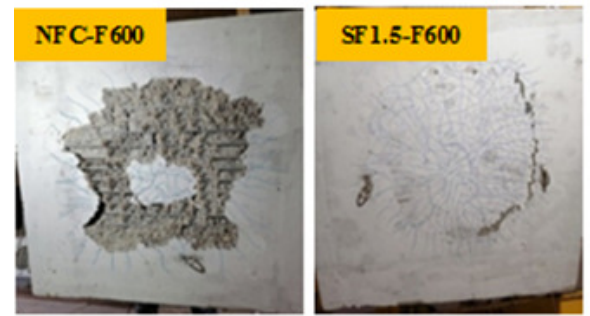

(c)
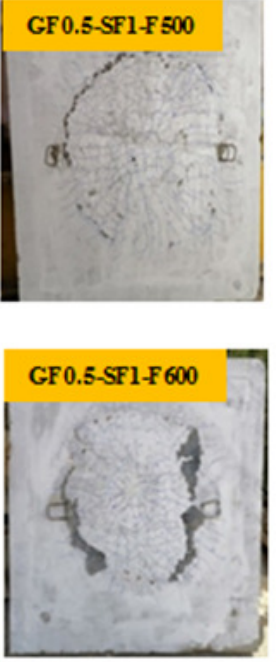

Fig. 7. Crack patterns in (a) Group 1,(b) Group 2, (c) Group 3.

\section{Area, Perimeter, and Angle of Failure}

For all the tested specimens, the punching failure mode had approximately the shape of a pyramid. Table VI illustrates the perimeter, the area, and the failure angle of the punching failure zone for the unburned and burned specimens. The failure angle was measured considering the dimensions of the crushed zone at the center line passing through the loaded area. Several studies indicated that fiber reinforced concrete slabs had failure angle higher than that in the normal reinforced concrete slabs where the smaller value of failure angle means wider base for the failure pyramid zone that's pushed out [20]. It can be concluded that, for both unburned and burned specimens, the failure angle for the fiber reinforced specimens was larger than that in the reference specimen in each group which means that the failure punching perimeter was smaller in the fiber reinforced specimens in comparison with the reference specimens. This usually belongs to the fiber contribution that prevents the disintegration in the concrete cover below the flexural steel reinforcement and helps to integrate the whole section. The results obtained in Group 1 indicate that the specimens with $1.5 \%$ steel fiber volume fraction had the highest decrease in the punching failure perimeter by about $20.7 \%$ in comparison with the reference specimen (NSC-NF). On the other hand, specimens containing two mixed types of fibers (steel and glass) showed the optimum modification in the perimeter of the failure punching by about $22 \%$ and $21.3 \%$ for Groups 2 and 3 respectively.
TABLE VI. PERIMETER, AREA AND FAILURE ANGLE

\begin{tabular}{|c|c|c|c|c|c|}
\hline Group & Specimen & $\begin{array}{c}\text { Perimeter } \\
(\mathbf{m m})\end{array}$ & $\begin{array}{c}\text { Perimeter } \\
\text { decrease }(\%)\end{array}$ & $\begin{array}{c}\text { Area } \\
\left(\mathbf{m m}^{2}\right)\end{array}$ & $\begin{array}{c}\text { Failure } \\
\text { angle }\left(\emptyset^{\circ}\right)\end{array}$ \\
\hline \multirow{3}{*}{1} & NFC-NF & 3080 & --- & 592900 & 17.9 \\
\hline & SF1.5-NF & 2440 & 20.7 & 372100 & 23.5 \\
\hline & $\begin{array}{c}\text { GF0.5-SF1- } \\
\text { NF }\end{array}$ & 2600 & 15.6 & 422500 & 21.8 \\
\hline \multirow{3}{*}{2} & NFC-F500 & 3640 & --- & 828100 & 14.7 \\
\hline & SF1.5-F500 & 3160 & 13.2 & 624100 & 17.3 \\
\hline & $\begin{array}{c}\text { GF0.5-SF1- } \\
\text { F500 }\end{array}$ & 2840 & 22 & 504100 & 19.6 \\
\hline \multirow{3}{*}{3} & NFC-F600 & 4120 & --- & 1060900 & 12.8 \\
\hline & SF $1.5-\mathrm{F} 600$ & 3560 & 13.6 & 792100 & 15.2 \\
\hline & $\begin{array}{c}\text { GF0.5-SF1- } \\
\text { F600 }\end{array}$ & 3240 & 21.3 & 656100 & 16.8 \\
\hline
\end{tabular}

\section{CONCLUSIONS}

The following conclusions can be drawn from the experimental work outcome:

- There is a reduction in the initial load crack and the ultimate load of the burned slabs compared with the corresponding unburned slabs. This reduction was improved by adding fiber to the specimens.

- After burning, random hair cracks were observed on each slab. These hair cracks were multiplied and more clearly observed in the specimens burned at $600^{\circ} \mathrm{C}$ than in the specimens burned at $500^{\circ} \mathrm{C}$.

- Adding fibers to the concrete has a significant effect on the punching failure perimeter zone, crack width, and concrete spalling for all the tested slabs (unburned and burned).

- Fiber reinforced slabs failed gradually in a more ductile mode. While the failure was sudden with brittle mode in slabs that contained no fibers.

- Steel fiber ratio $1.5 \%$ by volume had more effect in improving the response than the two mixed fibers (steel and glass) regarding the unburned specimens. For burned specimens, the two mixed fiber specimens had more improved response for both considered burning temperatures.

\section{REFERENCES}

[1] M. K. Jawad, "Experimental Study on shear heads in reinforced concrete flat plates," Ph.D. dissertation, Al-Mustansiriya University, Baghdad, Iraq, 2005.

[2] P. Menétrey, "Synthesis of punching failure in reinforced concrete," Cement and Concrete Composites, vol. 24, no. 6, pp. 497-507, Dec. 2002, https://doi.org/10.1016/S0958-9465(01)00066-X.

[3] G. A. Khoury, "Effect of fire on concrete and concrete structures," Progress in Structural Engineering and Materials, vol. 2, no. 4, pp. 429-447, 2000, https://doi.org/10.1002/pse.51.

[4] A. I. Abdullah and S. D. M. Al-Khazraji, "Structural Behavior of High Strength Laced Reinforced Concrete One Way Slab Exposed to Fire Flame," Civil Engineering Journal, vol. 5, no. 12, pp. 2747-2761, Dec. 2019, https://doi.org/10.28991/cej-2019-03091446.

[5] A. A. Hammadi, A. F. Izzat, and J. A. Farhan, "Effect of Fire Flame (High Temperature) on the Self Compacted Concrete (SCC) One Way Slabs," Journal of Engineering, vol. 18, no. 10, pp. 1083-1099, 2012. 
[6] S. Mohammed and N. Fawzi, "Fire Flame Influence on the Behavior of reinforced Concrete Beams Affected by Repeated Load," Journal of Engineering, vol. 22, no. 9, pp. 206-223, Sep. 2016.

[7] I. A. Fletcher, S. Welch, J. L. Torero, R. O. Carvel, and A. Usmani, "Behaviour of concrete structures in fire," Thermal Science, vol. 11, no. 2, pp. 37-52, 2007, https://doi.org/10.2298/TSCI0702037F.

[8] H. Salem, H. Issa, H. Gheith, and A. Farahat, "Punching shear strength of reinforced concrete flat slabs subjected to fire on their tension sides," HBRC Journal, vol. 8, no. 1, pp. 36-46, Apr. 2012, https://doi.org/10.1016/j.hbrcj.2011.10.001.

[9] M. I. M. Rjoub, "Moment capacity of steel fiber reinforced concrete beams," JES. Journal of Engineering Sciences, vol. 34, no. 2, pp. 413422, Mar. 2006, https://doi.org/10.21608/jesaun.2006.110462.

[10] S. T. Tassew and A. S. Lubell, "Mechanical properties of glass fiber reinforced ceramic concrete," Construction and Building Materials, vol. 51, pp. 215-224, Jan. 2014, https://doi.org/10.1016/j.conbuildmat. 2013.10.046.

[11] H. A. Hamid and S. D. Mohammed, "Behavior of Reinforced Reactive Powder Concrete Two-Way Slabs under Static and Repeated Load," Civil Engineering Journal, vol. 4, no. 6, pp. 1178-1192, Jul. 2018, https://doi.org/10.28991/cej-0309166.

[12] S. D. B. ALlexander and S. H. Simmonds, "Punching Shear Tests of Concrete Slab-Column Joints Containing Fiber Reinforcement," Structural Journal, vol. 89, no. 4, pp. 425-432, Jul. 1992, https://doi.org/10.14359/3027.

[13] R. K. Aboud, H. K. Awad, and S. D. Mohammed, "Fire flame effect on the compressive strength of reactive powder concrete using different methods of cooling," IOP Conference Series Materials Science and Engineering, no. 518, Nov. 2019, https://doi.org/10.1088/1757$899 X / 518 / 2 / 022029$.

[14] B. H. A. Bakar, A. T. Noaman, and H. M. Akil, "Cumulative Effect of Crumb Rubber and Steel Fiber on the Flexural Toughness of Concrete," Engineering, Technology \& Applied Science Research, vol. 7, no. 1, pp. 1345-1352, Feb. 2017, https://doi.org/10.48084/etasr.854.

[15] B. Gebretsadik, K. Jadidi, V. Farhangi, and M. Karakouzian, "Application of Ultrasonic Measurements for the Evaluation of Steel Fiber Reinforced Concrete," Engineering, Technology \& Applied Science Research, vol. 11, no. 1, pp. 6662-6667, Feb. 2021, https://doi.org/10.48084/etasr.3915.

[16] M. K. Jawad, "Experimental study on shear heads in reinforced concrete flat plates," M.S. thesis, University of Babylon, Al Hillah, Iraq, 2002.

[17] L. Nguyen-Minh, M. Rovňák, T. Tran-Quoc, and K. Nguyenkim, "Punching Shear Resistance of Steel Fiber Reinforced Concrete Flat Slabs," Procedia Engineering, vol. 14, pp. 1830-1837, Jan. 2011, https://doi.org/10.1016/j.proeng.2011.07.230.

[18] ACI Committee 318, ACI CODE-318-19: Building Code Requirements for Structural Concrete and Commentary. ACI, 2019.

[19] E. T. Dawood and M. Ramli, "Contribution of Hybrid Fibers on the Properties of High Strength Concrete Having High Workability," Procedia Engineering, vol. 14, pp. 814-820, Jan. 2011, https://doi.org/ 10.1016/j.proeng.2011.07.103.

[20] K.-K. Choi, H.-G. Park, and H.-M. Kim, "Shear Strength Model for Slab-Column Connections," Journal of the Korea Concrete Institute, vol. 22, no. 4, pp. 585-593, Aug. 2010, https://doi.org/10.4334/JKCI. 2010.22.4.585. 